\title{
PEMAHAMAN APARATUR PEMERINTAH TERHADAP PENERAPAN AKUNTANSI KEUANGAN DEMI TERCIPTANYA GOOD GOVERNANCE
}

\author{
Herlin \\ Yanto Effendi \\ Fakultas Ekonomi Universitas Dehasen Bengkulu \\ herlin olin81@yahoo.com
}

\begin{abstract}
ABSTRAK
Herlin dan Yanto Effendi: Tujuan penelitian ini untuk mengetahui pemahaman aparatur Pemerintah dalam penerapan akuntansi keuangan daerah guna mewujudkan good governance. Aparatur Pemerintah Kabupaten Rejang Lebong masih memiliki sedikit aparat/SDM yang berlatar belakang akuntansi, dari 25 responden, hanya 9 responden (36\%) yang berlatar belakang akuntansi dan sisanya berasal dari disiplin ilmu lainnya.

Hasil penelitian menunjukkan bahwa korelasi yang diperoleh nilai r sebesar 0, 203 adanya korelasi yang positif antara variabel $x$ dan variabel y dimana nilai $r$ terletak pada interval $0<r<1$, dan mempunyai tingkat hubungan yang rendah karna nilai $r$ terletak pada interval koefisien 0,20 - ,399. Nilai uji reliabilitas alpha yaitu 0,60 baru variabel dikatakan reliabel sehingga dari latar belakang pendidikan koefisien alpha sebesar 0,6123, pendidikan dan pelatihan koefisien alpha sebesar 0,622 serta Pengetahuan Mengenai Akuntansi Keuangan Daerah koefisien alpha sebesar 0,710. Nilai t-hitung < pada t-tabel, t-hitung sebesar 3,699 sedangkan t-tabel pada tingkat significant 0,05\% t-tabel sebesar 4,946, ini berarti tingkat pemahaman aparatur pemerintah di Kabupaten Rejang Lebong khususnya penerapan akuntasi keuangan masih lemah atau rendah, sehingga masih perlu peningkatan SDM melalui pendidikan, pelatihan, dan pemahaman tentang akuntansi keuangan yang sudah menjadi standar pemerintahan.
\end{abstract}

\section{ABSTRACT}

Herlin dan Yanto Effendi: The purpose of this study to determine the understanding of government apparatus in the area of financial accounting application in order to realize good governance. Government Personnel Rejang Lebong still has a bit of an apparatus / HR background in accounting, from 25 respondents, only 9 respondents (36\%) accounting background and the rest comes from other disciplines.

The results showed that the correlation obtained the $r$ value of 0,203 a positive correlation between the variables $x$ and $y$ variables where the value of $r$ lies in the interval $0<r<1$, and has a level of low relation because $r$ value lies in the interval coefficient of 0, 20 -, 399. Reliability test alpha value of 0.60 is said to be reliable so that the new variable of educational background alpha coefficient of 0.6123, the education and training of alpha coefficient of 0.622 and Awareness Regional Financial Accounting alpha coefficient of 0.710. T-count value <the t-table, $t$-count equal to 3,699 while the $t$-table at significant level of $0.05 \%$ t-table of 4,946, this means that the level of understanding of government officials in Rejang Lebong specifically the application of financial accounting still weak or low, so they need to increase human resources through education, training, and understanding of financial accounting has become a standard government.

Key words: Good Governance.

\section{PENDAHULUAN}

Krisis ekonomi melanda Indonesia memberikan dampak positif dan negatif bagi upaya peningkatan kesejahteraan seluruh rakyat Indonesia. Krisis ekonomi dan kepercayaan yang dialami telah membuka jalan bagi munculnya reformasi total di seluruh aspek kehidupan bangsa Indonesia. Tema sentral reformasi total tersebut adalah mewujudkan masyarakat madani, terciptanya good governance dan mengembangkan model pembangunan yang berkeadilan menurut Mardiasmo (2009). Menurut UU No. 22 Tahun 1999 dan UU No. 25 Tahun 1999 yang mengatur tentang otonomi daerah dan desentralisasi fiskal merupakan era baru bagi daerah untuk mengelola daerah masing-masing, baik di tingkat provinsi, maupun di tingkat kabupaten dan kabupaten. Dalam perkembangannya kebijakan tersebut diperbaharui dengan ditetapkannya UU No. 32 Tahun 2004 dan UU No. 33 Tahun 2004 yang mengatur tentang pemerintah Daerah dan Perimbangan Keuangan antara Pemerintah Pusat dan Pemerintah Daerah. Undang-Undang ini telah menyebabkan perubahan yang mendasar mengenai pengaturan hubungan pusat 
dan daerah. Khususnya perubahan dalam bidang administrasi pemerintahan maupun dalam hubungan keuangan antara Pemerintah Pusat dan Daerah yang dikenal sebagai era otonomi daerah. Semakin luasnya kewenangan yang dimiliki pemerintah daerah, maka semakin besar pula tanggung jawab yang diemban oleh pemerintah kepada publik. Perubahan mendasar dalam pengelolaan keuangan daerah merupakan wujud dari adanya tuntutan publik terhadap akuntabilitas dan transparansi manajemen pemerintahan, salah satunya adalah terkait dengan manajemen keuangan negara maupun daerah". (Tuasikal, 2007).

Perubahan mendasar dalam manajemen keuangan daerah pasca reformasi keuangan dengan dilaksanakannya pengelolaan keuangan daerah oleh pemerintah, baik pemerintah daerah provinsi maupun kabupaten, bukan pembukuan seperti yang dilaksanakan selama ini (Mardiasmo, 2009). Manajemen keuangan daerah merupakan alat untuk mengurus dan mengatur rumah tangga pemerintah daerah. Salah satu bagian dari manajemen keuangan daerah tersebut adalah akuntansi keuangan daerah yang merupakan salah satu bentuk tata usaha dalam manajemen keungan daerah selain tata usaha umum atau administrasi. Akuntansi keuangan daerah tersebut merupakan bagian dari akuntansi sektor publik di mana tingkatan tertinggi dalam sektor publik adalah tingkatan negara. Oleh karenanya, akuntansi keuangan daerah berhubungan dengan akuntansi keuangan negara.

Pedoman pengelolaan keuangan daerah, pemerintah mengeluarkan Peraturan Menteri Dalam Negeri (Permendagri) No. 13 Tahun 2006 tentang Pedoman Pengelolaan Keuangan Daerah yang telah direvisi dengan Permendagri No. 59 Tahun 2007 dan Peraturan Pemerintah (PP) No. 24 Tahun 2005 tentang Standar Akuntansi Pemerintahan (SAP) serta peraturan pelaksana lainnya. Dengan adanya peraturan perundangan tersebut pemerintah daerah diwajibkan untuk mengelola keuangan daerah dengan baik sesuai ketentuan dan standar yang telah ditetapkan.

Pengelola keuangan daerah harus memiliki pemahaman yang memadai tentang sistem akuntansi keuangan daerah agar dapat menyajikan laporan keuangan yang handal dan berkualitas. Keberadaan laporan keuangan pemerintah daerah tersebut sangat penting sebagai wujud pelaksanaan transparansi dan akuntabilitas publik dalam rangka menciptakan good governance. Untuk itu Sumber Daya Manusia (SDM) sebagai pengelola keuangan pemerintah daerah harus memiliki pemahaman mengenai akuntansi keuangan daerah.

Akuntansi pemerintahan yang selama ini diterapkan ternyata belum dapat memenuhi keinginan publik. Beberapa kelemahan dalam sistem administrasi negara menimbulkan berbagai kelemahan dalam laporan keuangan pemerintah. Penerapan akuntansi keuangan daerah yang merupakan bagian dari akuntansi sektor publik menimbulkan kekhawatiran banyak pihak. Hal ini disebabkan karena banyak pihak meragukan kesiapan dan kompetensi aparat atau sumber daya manusia yang ada pada instansi pemerintah untuk menerapkan akuntansi keuangan daerah yang merupakan sistem akuntansi yang relatif baru yang disiapkan dalam rangka menciptakan akuntabilitas publik di Indonesia.

\section{LANDASAN TEORI Pengertian Keuangan Daerah}

Menurut Permendagri No.13 Tahun 2006 yang telah direvisi dengan Permendagri No. 59 Tahun 2007 tentang Pedoman Pengelolaan Keuangan Daerah pasal 1 ayat 6, keuangan daerah adalah semua hak dan kewajiban daerah dalam rangka penyelenggaraan pemerintahan daerah yang dapat dinilai dengan uang, termasuk di dalamnya segala bentuk kekayaan yang berhubungan dengan hak dan kewajiban daerah tersebut. Dalam Halim (2007:50), menyatakan keuangan daerah dapat juga diartikan sebagai semua hak dan kewajiban yang dapat dinilai dengan uang, demikian pula segala sesuatu baik berupa uang maupun barang yang dapat dijadikan kekayaan daerah sepanjang belum dimiliki atau dikuasai oleh negara atau daerah yang lebih tinggi serta pihak-pihak lain sesuai ketentuan/peraturan perundangan yang berlaku.

Menurut Peraturan Menteri Dalam Negeri (Permendagri) No. 13 Tahun 2006 tentang Pedoman Pengelolaan Keuangan Daerah, ruang lingkup keuangan daerah meliputi:

a. hak daerah untuk memungut pajak daerah dan retribusi daerah serta melakukan pinjaman;

b. kewajiban daerah untuk menyelenggarakan urusan pemerintahan daerah dan membayar tagihan pihak ketiga;

c. penerimaan daerah;

d. pengeluaran daerah;

e. kekayaan daerah yang dikelola sendiri atau oleh pihak lain berupa uang, surat berharga, piutang, barang, serta hak-hak lain yang dapat dinilai dengan uang, termasuk kekayaan yang dipisahkan pada perusahaan daerah; 
f. kekayaan pihak lain yang dikuasai oleh pemerintah daerah dalam rangka penyelenggaraan tugas pemerintahan daerah dan/atau kepentingan umum.

Dalam Permendagri No. 13 Tahun 2006 pasal 6 ayat 1 dan 3, kepala daerah selaku kepala pemerintah daerah adalah pemegang kekuasaan pengelolaan keuangan daerah dan mewakili pemerintah daerah dalam kepemilikan kekayaan daerah yang dipisahkan. Kepala daerah selaku pemegang kekuasaan pengelolaan keuangan daerah melimpahkan sebagian atau seluruh kekuasaannya kepada:

a. Sekretaris daerah selaku koordinator pengelola keuangan daerah;

b. Kepala Satuan Kerja Pengelola Keuangan Daerah (SKPKD) selaku Pejabat Pengelola Keuangan Daerah (PPKD); dan

c. Kepala Satuan Kerja Perangkat Daerah (SKPD) selaku pejabat pengguna anggaran/pengguna barang.

\section{Karakteristik Pengelolaan Keuangan Daerah}

Pengelolaan keuangan pemerintah daerah, yang ditandai dengan keluarnya UU No. 32 Tahun 2004 tentang Pemerintah Daerah dan UU No. 33 Tahun 2004 tentang Perimbangan Keuangan antara Pemerintah Pusat dan Daerah menyebabkan terjadinya transformasi paradigmatik dalam pengelolaan keuangan daerah yang ditandai dengan adanya :

1. Desentralisasi

2. Aspirasi, Partisipasi, dan Demokratisasi

3. Value for Money

4. Keadilan

5. Transparansi dan Akuntabilitas Publik

\section{Hubungan Keuangan Negara dengan Keuangan Daerah Dalam Rangka Otonomi Daerah.}

Hubungan antara keuangan negara dan keuangan daerah yang merupakan dasar pengelolaan keuangan daerah, sehingga baik dalam penyusunan APBD dan pelaporan keuangan daerah maupun pelaksanaannya mencerminkan pelaksanaan otonomi daerah yang nyata dan bertanggung jawab menurut Bastian (2010) mencakup hal-hal sebagai berikut :

a. Harus serasi dengan pembinaan politik dan kesatuan bangsa.

b. Harus dapat menjamin hubungan yang serasi antara pemerintah pusat dan pemerintah daerah atas dasar keutuhan negara kesatuan.

c. Harus dapat menjamin perkembangan dan pembangunan daerah termasuk prisip-prinsip pembagian sumber-sumber keuangan yang adil.

d. Mampu memberdayakan dan meningkatkan kemampuan perekonomian daerah.

e. Dapat menciptakan sistem pembiayaan daerah yang adil, proporsional, rasional, transparan, partisipatif, bertanggung jawab (akuntabel) dan pasti.

\section{Akuntansi Keuangan Daerah}

Halim (2007) mendefinisikan akuntansi keuangan daerah sebagai suatu proses identifikasi, pengukuran dan pelaporan transaksi ekonomi (keuangan) dari suatu daerah (provinsi, kabupaten, atau kabupaten) yang dijadikan sebagai informasi dalam pengambilan keputusan ekonomi oleh pihak-pihak yang memerlukan.

Akuntansi keuangan daerah adalah serangkaian kegiatan yang dilakukan secara sistematis di bidang keuangan berdasarkan prinsip-prinsip, standar-standar serta prosedur tertentu yang menghasilkan informasi aktual di bidang keuangan menurut Tuasikal dalam buku Pengaruh Pemahaman Sistem Akuntansi.

\section{Lingkungan Akuntansi Keuangan Daerah}

Laporan keuangan yang dihasilkan oleh akuntansi keuangan daerah digunakan oleh berbagai pihak. Pihak-pihak yang terlibat dan berkepentingan terhadap pemerintah daerah baik langsung maupun tidak langsung disebut pemakai laporan keuangan pemerintah daerah. Pemakai laporan keuangan pemerintah daerah tersebut menurut Halim (2007) adalah :
1. DPRD
2. Badan Eksekutif
3. Badan Pengawas Keuangan (BPK)
4. Investor, Kreditur dan Donatur 
5. Analis Ekonomi dan Pemerhati Pemerintah Daerah

6. Rakyat

7. Pemerintah Pusat

\section{Laporan Keuangan Pemerintah Daerah}

Untuk sektor publik, dalam rangka pertanggungjawaban pelaksanaan APBD, pemerintah selaku entitas pelaporan diwajibkan menyusun laporan keuangan yang meliputi (PP No. 24 Tahun 2005 tentang Standar Akuntansi Pemerintahan):

1. Laporan Realisasi Anggaran

2. Neraca

3. Laporan Arus Kas

4. Catatan Atas Laporan Keuangan

\section{Pengertian Good Governance}

Good governance merupakan aspek penting dalam mewujudkan pengelolaan keuangan yang dapat dipertanggungjawabkan. Menurut Mardiasmo (2009), good governance didefinisikan sebagai suatu penyelenggaraan manajemen pembangunan yang solid dan bertanggung jawab yang sejalan dengan prinsip demokrasi dan pasar yang efisien, penghindaran salah alokasi dana investasi, dan pencegahan korupsi baik secara politik maupun administratif, menjalankan disiplin anggaran serta penciptaan legal dan political framework bagi tumbuhnya aktivitas usaha.

\section{Karakteristik Good Governance}

Karakteristik dalam pelaksanaan good governance yang diberikan UNDP menurut Mardiasmo

(2009) meliputi :

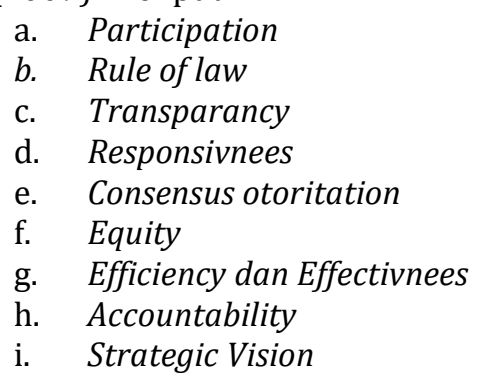

\section{Tujuan Penerapan Good Governance}

Dalam menegakkan sistem good governance, menurut Mardiasmo (2009) dalam suatu organisasi diharapkan terjadi peningkatan dalam hal :

1. Efisiensi, efektivitas dan kesinambungan suatu organisasi yang memberikan kontribusi kepada terciptanya kesejahteraan masyarakat, pegawai dan stakeholder lainnya dan merupakan solusi yang elegan dalam menghadapi tantangan organisasi ke depan.

2. Legitimasi organisasi yang dikelola dengan terbuka, adil dan dapat dipertanggungjawabkan.

3. Mengakui dan melindungi hak dan kewajiban para stakeholder.

4. Pendekatan yang terpadu berdasarkan kaidah-kaidah demokrasi, pengelolaan dan partisipasi organisasi secara legitimate.

Tanpa memiliki organisasi yang efisien, suatu negara akan sulit untuk menciptakan kemakmuran dan kesejahteraan bagi masyarakatnya. Untuk itulah good governance menjadi sebuah kebutuhan pokok dalam pembangunan ekonomi nasional.

\section{Standar Akuntansi Pemerintahan (SAP)}

Salah satu upaya konkrit untuk mewujudkan transparansi dan akuntabilitas pengelolaan keuangan negara adalah penyampaian laporan pertanggungjawaban keuangan pemerintah yang memenuhi prinsip tepat waktu dan disusun dengan mengikuti standar akuntansi pemerintahan yang telah diterima secara umum. Hal tersebut diatur dalam Undang-Undang N0. 17 Tahun 2003 tentang Keuangan Negara yang mensyaratkan bentuk dan isi laporan pertanggungjawaban pelaksanaan APBN/APBD disusun dan disajikan sesuai dengan standar akuntansi pemerintahan yang ditetapkan dengan peraturan pemerintah (Komite Standar Akuntansi Pemerintahan, 2005).

Standar Akuntansi Pemerintahan yang selanjutnya disebut SAP adalah prinsip-prinsip akuntansi yang diterapkan dalam menyusun dan menyajikan laporan keuangan pemerintah. Dengan 
demikian, SAP merupakan persyaratan yang mempunyai kekuatan hukum dalam upaya meningkatkan kualitas laporan keuangan pemerintah di Indonesia (Komite Standar Akuntansi Pemerintahan, 2005). SAP dinyatakan dalam bentuk Pernyataan Standar Akuntansi Pemerintahan (PSAP) yang terdiri dari:

1. PSAP Nomor 01 tentang Penyajian Laporan Keuangan

2. PSAP Nomor 02 tentang Laporan Realisai Anggaran

3. PSAP Nomor 03 tentang Laporan Arus Kas.

4. PSAP Nomor 04 tentang Catatan atas Laporan Keuangan.

5. PSAP Nomor 05 tentang Akuntansi Persediaan.

6. PSAP Nomor 06 tentang Akuntansi Investasi.

7. PSAP Nomor 07 tentang Akuntansi Aset Tetap.

8. PSAP Nomor 08 tentang Akuntansi Konsrtuksi Dalam Pengerjaan.

9. PSAP Nomor 09 tentang Akuntansi Kewajiban.

10. PSAP Nomor 10 tentang Koreksi Kesalahan, Perubahan Kebijakan Akuntansi, dan Peristiwa Luar Biasa.

11. PSAP Nomor 11 tentang Laporan Keuangan Konsolidasian.

\section{Kerangka Analisis}

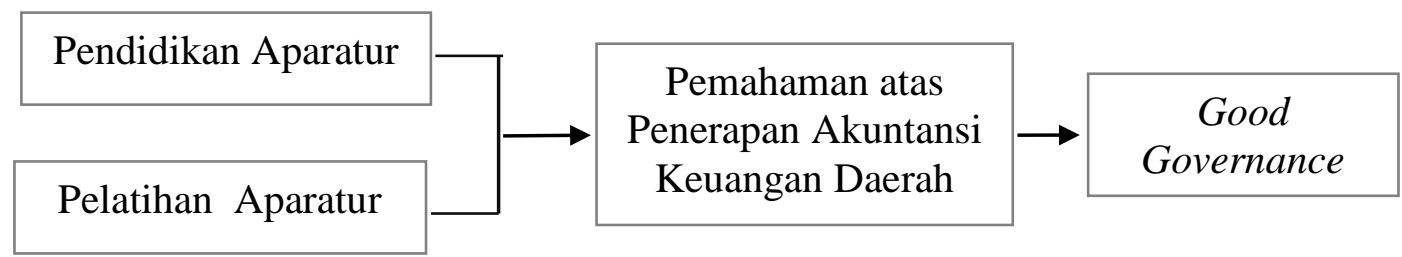

\section{Gambar 1. Kerangka analisis}

Dari kerangka analisis diatas dapat dijelaskan bahwa Pendidikan dan pengetahuan Aparatur Pemerintah Kabupaten Rejang Lebong dengan Pemahaman aparatur terhadap Akuntansi Keuangan Daerah adalah faktor penting dan saling membutuhkan satu sama lain untuk mewujudkan Pemerintahan yang Good Governance di Pemerintahan Kabupaten Rejang Lebong.

\section{METODE PENELITIAN}

Penelitian ini adalah penelitian deskriptif (descriptive research) yaitu penelitian terhadap masalah-masalah berupa fakta-fakta saat ini dari suatu populasi. Tujuan penelitian deskriptif adalah untuk menguji hipotesis atau menjawab pertanyaan yang berkaitan dengan current status dari subyek. Metode pengambilan sampel yang digunakan dalam penelitian ini adalah purposive sampling yaitu pemilihan sampel bertujuan. Penyebaran kuisioner sebanyak di bagian keuangan yang berhubungan dengan akuntansi keuangan daerah sehingga sesuai dengan yang diharapkan dalam penelitian ini. Dalam penelitian ini sampel yang diambil sebanyak 30 sampel, dari 6 SKPD yang ada diKabupaten Rejang Lebong.

Data yang digunakan dalam penelitian ini adalah data primer. Data primer merupakan sumber data penelitian yang diperoleh secara langsung dari sumber asli/tidak melalui media perantara (Indrianto dan Supomo, 2002). Teknik yang digunakan dalam mengumpulkan data primer ini, yaitu dengan metode kusioner. Dalam kuisioner penelitian ini, pertanyaan yang diajukan hanya terdiri dari pertanyaan tertutup yang berjumlah 25 pertanyaan. Dari be berapa pertanyaan yang akan diajukan mencakup latar belakang tingkat pendidikan aparatur, tingkat pelatihan apartur dan tingkat pemahaman aparatur terhadap akuntansi keuangan daerah Rejang Lebong. Metode Analisis menggunakan:

1. Metode Kualitatif

Metode kualitatif ini dilakukan untuk membandingkan apa yang telah dilakukan oleh pemerintahan khususnya Kabupaten Rejang Lebong dan teori yang relevan serta hasil-hasil yang telah dicapai. Penggunaan metode kualitatif ini bertujuan agar memperoleh hasil yang optimal sehingga penelitian ini dapat mencapai tujuan yang diharapkan.

2. Metode Kuantitatif

Metode kuantitatif merupakan metode yang didasarkan perhitungan matematis dengan menggunakan metode statistik dengan rumus :

a. Korelasi Product moment Pearson 
Metode yang digunakan untuk mengetahui validitas instrumen penelitian pada penelitian ini adalah dengan mengkorelasikan antara skor individu yang diperoleh masingmasing item atau butir dengan skor total dari masing-masing item. Penelitian ini menggunakan teknik korelasi Product Moment Pearson dengan rumus sebagai berikut:

$$
\mathrm{r}_{\mathrm{xy}}=\frac{\mathrm{n} \Sigma \mathrm{XY}-\Sigma \mathrm{X} \cdot \Sigma \mathrm{Y}}{\sqrt{\left(\left(\mathrm{n} \Sigma \mathrm{X}^{2}\right)-(\Sigma \mathrm{X})^{2}\right)\left(\left(\mathrm{n} \Sigma \mathrm{Y}^{2}\right)-\left(\sum \mathrm{Y}\right)^{2}\right)}}
$$

Keterangan:

rxy $=$ Koefisien korelasi Product Moment

$\mathrm{n}=$ Banyaknya sampel yang diuji

$\mathrm{X}=$ Skor masing-masing pertanyaan

$\mathrm{Y}=$ Skor Total

Kriteria yang ditetapkan dalam menentukan validitas data adalah $r$ hitung (koefisien korelasi) lebih besar dari $r$ tabel (nilai kritis) pada taraf signifikan 0,05. Jadi, jika koefisien korelasinya lebih besar dari nilai kritisnya maka instrumen pengukur dapat dikatakan valid (Ghozali, 2005).

b. Uji Reliabilitas

Reliabilitas adalah indeks yang menunjukkan sejauh mana suatu alat pengukur dapat dipercaya atau dapat diandalkan. Suatu kuisioner dikatakan reliabel atau handal jika jawaban seseorang terhadap pertanyaan adalah konsisten atau stabil dari waktu ke waktu (Ghozali, 2005).

Dalam penelitian ini pengujian reliabilitas menggunakan analisis Cronbach's Alpha dengan rumus sebagai berikut:

$$
\mathrm{r}_{11}=[]\left[1-\frac{\mathrm{k}}{(\mathrm{k}-1)}\right] \quad \frac{\sum \sigma_{\mathrm{b}}{ }^{2}}{\sigma_{\mathrm{t}^{2}}}
$$

Keterangan:

$\mathrm{r}_{11}=$ reliabilitas instrumen

$\mathrm{k}$ = banyaknya butir pertanyaan

$\sum \sigma_{b}^{2}=$ jumlah varians butir

$\Sigma_{\mathrm{t}^{2}}=$ varians total

Kriteria yang ditetapkan dalam mengetahui reliabilitas data adalah nilai koefisien reliabilitas alpha yang lebih besar dari 0,60 (Nunnally, 1967 dalam Ghozali, 2005). Jadi, jika nilai koefisien reliabilitas alpha-nya lebih besar dari 0,60 maka instrumen pengukur dapat dikatakan reliabel atau handal.

c. Uji Validitas $\mathrm{t}$-hitung

t- hitung $=\frac{r \sqrt{n}-2}{\sqrt{1-r^{2}}}$

Dimana :

$\mathrm{t}=\mathrm{t}$-hitung

$\mathrm{r}=$ koefisien korelasi

$\mathrm{n}=$ jumlah sampel

Dengan membandingkan $\mathrm{t}$ hasil perhitungan dengan $\mathrm{t}$ tabel pada derajad kebebasan( $\mathrm{d}-\mathrm{k})$

$=(\mathrm{n}-\mathrm{k})$ dan pada tingkat keyakinan $95 \%(0,05)$ maka :

Bila t hitung $<\mathrm{t}$ tabel : Ho diterima

Bila t hitung $>\mathrm{t}$ tabel : Ho ditolak.

\section{HASIL PENELITIAN DAN PEMBAHASAN Deskripsi Data}

Data dalam penelitian ini berasal dari data primer yaitu kuisioner. Jumlah kuisioner yang disebar sebanyak 30 kuisioner dan kuisioner yang kembali sebanyak 25 kuisioner, sehingga tingkat pengembalian kuisioner sebesar 83\%. Rincian mengenai tingkat pengembalian responden terhadap kuisioner ini dapat dilihat pada tabel berikut ini: 
Tabel 1 : Deskripsi Data

\begin{tabular}{|l|c|c|}
\multicolumn{1}{|c|}{ Keterangan } & Banyaknya & Persentase (\%) \\
\hline Kuisioner yang disebarkan & 30 & $100 \%$ \\
\hline Kuisioner yang dikembalikan & 25 & $83 \%$ \\
\hline Kuisioner tidak lengkap & 0 & $0 \%$ \\
\hline Kuisioner diolah & 25 & $83 \%$ \\
\hline
\end{tabular}

Sumber : Hasil Pengolahan data kuesioner Mei 2013

\section{Deskripsi Responden}

Dari 25 data responden yang dapat dianalisis diperoleh deskripsi responden yang dibagi berdasarkan jenis kelamin, pendidikan terakhir, masa kerja dan jabatan/posisi. Berdasarkan jenis kelamin, dalam penelitian ini terdapat 16 responden (64\%) Wanita dan 9 responden (36\%) Pria. Pendidikan terakhir terdapat 12 responden (48\%) berpendidikan SMA/sederajat; 5 responden (20\%) berpendidikan D3 dari jurusan akuntansi, manajemen informatika, dan administrasi; 7 responden (28\%) berpendidikan S1 yang berasal dari berbagai jurusan yaitu akuntansi, manajemen, administrasi negara, Manajemen keuangan Sedangkan sisanya, 1 responden (4\%) berpendidikan S2 konsentrasi Akuntansi sektor publik, dan tidak ada responden yang berpendidikan S3. Gambaran mengenai pendidikan terakhir responden dapat dilihat dari tabel berikut:

Berdasarkan masa kerja, ada 6 responden (24\%) dengan masa kerja 1-5 tahun; 10 responden (40\%) dengan masa kerja 6-10 tahun; 4 responden (16\%) dengan masa kerja 11-15 tahun; 2 responden (8\%) dengan masa kerja 16-20 tahun; 2 responden (8\%) dengan masa kerja 21-25 tahun; 1responden (4\%) dengan masa kerja $>25$ tahun

Berdasarkan jabatan/posisi responden, dapat diketahui bahwa 13 responden (52\%) adalah staf; 5 responden (20\%) adalah Kasi; 3 responden (12\%) adalah Kasubag; 2 responden (8\%) adalah Kabag; 2 responden (8\%) adalah Bendahara.

\section{PEMBAHASAN}

a. Perhitungan korelasi produc moment pearson

$$
\begin{aligned}
& r_{x y}=\frac{n\left(\sum X Y\right)-\left(\sum X\right)\left(\sum Y\right)}{\sqrt{\left(\left(n \sum X^{2}\right)-\left(\sum X\right)^{2}\right)\left(\left(n \sum Y^{2}\right)-\left(\sum Y\right)^{2}\right)}} \\
& r_{x y}=\frac{25(8869)-(470)(470)}{\sqrt{\left(25(8966)-(470)^{2}\right)\left(\left(25(9038)-(470)^{2}\right)\right.}} \\
& r_{x y}=\frac{221725-220900}{\sqrt{(224150-220900)(225950-220900)}} \\
& r_{x y}=\frac{825}{\sqrt{(3250 \times 5050)}} \\
& r_{x y}=\frac{825}{57,008 \times 71,063}
\end{aligned}
$$

$r_{x y}=\frac{825}{4051}$

$\operatorname{rxy}=0,203$

Dari hasil perhitungan korelasi diatas diperoleh nilai r sebesar 0,203 yang menjelaskan bahwa terjadi korelasi positif antara variabel $\mathrm{x}$ dan y karena nilai $\mathrm{r}$ terletak pada interval $0<\mathrm{r}<$ 
1 dan mempunyai tingkat pemahaman dalam penerapan akuntansi yang rendah karena nilai $\mathrm{r}$ terletak pada interval koefisien $0,20-0,399$.

b. Uji Reliabilitas

Kuisioner dapat dikatakan reliabel jika jawaban terhadap pernyataan adalah konsisten atau stabil dari waktu ke waktu. Variabel dikatakan reliabel jika memberikan nilai Cronbach's Alpha lebih besar dari 0,60 (Nunnally, 1967 dalam Ghozali, 2005). Reliabilitas pengujian yang dihasilkan untuk setiap variabel dalam penelitian ini adalah lebih besar daripada 0.60 jadi dapat disimpulkan bahwa kuisioner ini reliabel. Hasil pengujian reabilitas variabel latar belakang pendidikan, pendidikan dan pelatihan, dan pengetahuan mengenai akuntansi keuangan daerah adalah sebagai berikut:

c. Uji Validitas $\mathrm{t}$ - hitung

$$
\begin{aligned}
t-\text { hitung } & =\frac{\mathrm{r} \sqrt{\mathrm{n}-2} 0,203}{\sqrt{1-\mathrm{r}^{2}}} \frac{\sqrt{25-2}}{\sqrt{1-0,041}} \\
& =\frac{0,203(4,79)}{1-0,797} \\
& =\frac{0,751}{0,203} \\
& =3,699
\end{aligned}
$$

Dari hasil perhitungan uji t maka diperoleh t.hitung lebih kecil dari t.tabel dimana t-hitung sebesar 3,699 sedangkan t tabel pada tingkat significant 0,05 \% sebesar 4,946. Dengan demikian Ha ditolak dan Ho diterima yang berarti perlu adanya peningkatan pemahaman aparatur pemerintah Kabupaten Rejang Lebong dalam penerapan akuntansi keuangan daerah demi menuju terciptanya good governance dan perlu juga adanya peningkatan Sumber Daya Manusia melalui pelatihan dan pendidikan.

\section{Kesimpulan}

Aparatur Pemerintah Kabupaten Rejang Lebong masih memiliki sedikit aparat/SDM yang berlatar belakang akuntansi. Dari 25 responden, hanya 9 responden (36\%) yang berlatar belakang akuntansi. Sisanya berasal dari disiplin ilmu lainnya. Kurangnya aparatur/SDM tersebut akan menghambat penerapan akuntansi keuangan daerah di Kabupaten Rejang Lebong. Korelasi diperoleh nilai r sebesar 0, 203 adanya korelasi yang positif antara variabel $\mathrm{x}$ dan variabel y dimana nilai $r$ terletak pada interval $0<\mathrm{r}<1$, dan mempunyai tingkat hubungan yang rendah karna nilai $\mathrm{r}$ terletak pada interval koefisien 0,20 - ,399. Nilai uji reliabilitas alpha yaitu 0,60 baru variabel dikatakan reliabel sehingga dari latar belakang pendidikan koefisien alpha sebesar 0,6123, pendidikan dan pelatihan koefisien alpha sebesar 0,622 serta Pengetahuan Mengenai Akuntansi Keuangan Daerah koefisien alpha sebesar 0,710. Nilai t-hitung < pada t-tabel, t-hitung sebesar 3,699 sedangkan t-tabel pada tingkat significant 0,05 \% t-tabel sebesar 4,946, ini berarti tingkat pemahaman aparatur pemerintah di Kabupaten Rejang Lebong khususnya penerapan akuntasi keuangan masih lemah atau rendah, sehingga masih perlu peningkatan SDM melalui pendidikan, pelatihan, dan pemahaman tentang akuntansi keuangan yang sudah menjadi standar pemerintahan.

\section{Saran}

Pemerintah Daerah Kabupaten Rejang Lebong diharapkan dapat memberikan seminar, pendidikan dan pelatihan mengenai akuntansi keuangan daerah secara intensif kepada aparatur pemerintahan dan dapat bekerja sama dengan pihak-pihak yang kompeten untuk meningkatkan pemahaman mengenai akuntansi keuangan daerah, sehingga dapat terwujud penerapan akuntansi keuangan daerah dan terciptanya good governance. 


\section{DAFTAR PUSTAKA}

Bastian, Indra. 2010. Akuntansi Sektor Publik: Suatu Pengantar. Yogyakarta: BPFE.

Ghozali, Imam. 2005. Aplikasi Analisis Multivariate dengan Program SPSS. Edisi Ketiga. Semarang: Badan Penerbit Universitas Diponegoro.

Halim, Abdul. 2007. Akuntansi Sektor Publik: Akuntansi Keuangan Daerah. Jakarta: Salemba Empat.

Komite Standar Akuntansi Pemerintahan. 2005. Peraturan Pemerintah No. 24 Tahun 2005 tentang Standar Akuntansi Pemerintahan (SAP). Jakarta: Salemba Empat.

Mardiasmo. 2009. Akuntansi Sektor Publik. Yogyakarta: Penerbit Andi.

Republik Indonesia. Peraturan Menteri Dalam Negeri No. 13 Tahun 2006 tentang Pedoman Pengelolaan Keuangan Daerah yang Diperbaharui dengan Permendagri No. 59 Tahun 2007.

Tuasikal, Askam. 2007. Pengaruh Pemahaman Sistem Akuntansi, Pengelolaan Keuangan Daerah terhadap Kinerja Satuan Kerja Pemerintah Daerah Jurnal Akuntansi Keuangan dan Sektor Publik, 01; 14661483.

. UU No. 32 Tahun 2004 tentang Pemerintah Daerah.

. UU No. 33 Tahun 2004 tentang Perimbangan Keuangan antara Pemerintah Pusat dan Daerah.

Organisasi Perangkat Daerah (2008) (Online) (Diakses tanggal 19 Januari 2009) tersedia di World Wide Web: http//kotabengkulu.go.id

. PP No. 58 Tahun 2005 tentang Pengelolaan Keuangan Daerah.

. UU No. 17 Tahun 2003 tentang Keuangan Negara.

. UU No. 22 Tahun 1999 tentang Pemerintah Daerah.

UU No. 25 Tahun 1999 tentang Perimbangan Keuangan antara Pemerintah Pusat dan Pemerintah Daerah.

Yulianti, Septi. 2006. Pemahaman Aparat Instansi Pemerintah Kabupaten Lahat dalam Penerapan Akuntansi Keuangan Daerah Menuju Terciptanya Good Governance. Skripsi tidak dipublikasikan. Inderalaya. Fakultas Ekonomi Universitas Sriwijaya. 